удК 339.146.51.7

\title{
СТВОРЕННЯ БРЕНДУ ЯК ЗАСІБ ФОРМУВАННЯ ТУРИСТИЧНОЇ ПРИВАБЛИВОСТІ РЕГІОНУ
}

\section{CREATION OF A BRAND AS A MEANS OF FORMING THE TOURIST ATTRACTIVENESS OF THE REGION}

\author{
Сидорук Анна Вікторівна \\ кандидат педагогічних наук, доцент, \\ Запорізький національний університет \\ ORCID: https://orcid.org/0000-0002-8466-6912 \\ Остапенко Людмила Вікторівна \\ кандидат педагогічних наук, начальник відділу іміджевих проектів \\ та маркетингу управління туризму, \\ Департамент культури і туризму Запорізької міської ради \\ ORCID: https://orcid.org/0000-0002-1770-9791 \\ Шугай Яна Максимівна \\ кандидат педагогічних наук, викладач, \\ КВНЗ «Хортицька навчально-реабілітаційна академія» \\ ORCID: https://orcid.org/0000-0002-2325-6303 \\ Sydoruk Anna \\ Zaporizhzhya National University \\ Ostapenko Lyudmila \\ Department of Culture and Tourism of Zaporizhia City Council \\ Shuhay Yana \\ Municipal Institution of Higher Education \\ «Khortytsia National Educational Rehabilitation Academy»
}

\begin{abstract}
Стаття присвячена актуальності розвитку туристичної галузі й індустрії гостинності у сучасному світі. Визначено проблеми та перспективи розвитку туристичної привабливості у регіонах. Виокремлено вплив брендингу на формування позитивного іміджу території, підвищення рівня ії конкурентоспроможності та економічного розвитку. Проаналізовано погляди видатних вітчизняних і зарубіжних наукових діячів щодо визначення поняття «бренд», виконано їх співвідношення та ссрормовано поняття «регіональний туристичний бренд», як сукупність елементів, які ідентифікують туристичний продукт або послугу, що надає окремий регіон, серед конкурентів і визначають їх відмінність на туристичному ринку. Схарактеризовано, що в сучасних умовах брендинг регіону - це найбільш результативний інструмент його динамічного позиціонування, в якому вимальовується витривала тенденція визначати регіональний брендинг як цілісність неминущих цінностей, виняткових і автентичних характеристик відповідної території та спільноти, котрі отримали все загальне визнання й користуються популярністю серед різних груп стейкхолдерів.
\end{abstract}

Ключові слова: туристична галузь, індустрія гостинності, брендинг, бренд, туристична привабливість, регіон.

Статья посвящена актуальности развития туристической отрасли и индустрии гостеприимства в современном мире. Определены проблемы и перспективы развития туристической привлекательности в регионах. Выделены влияние брендинга на фрормирование положительного имиджа территории, повышение уровня его конкурентоспособности и экономического развития. Проанализированы взгляды выдающихся отечественных и зарубежных научных деятелей относительно определения понятия «бренд», выполнено их соотношение и сорормировано понятие «региональный туристический бренд», как совокупность элементов, которые идентифрицируют туристический продукт или услугу, которые предоставляет отдельный регион, среди конкурентов и определяют их отличие в туристическом рынке. Охарактеризовано, что в современных условиях брендинг региона - это наиболее результативный инструмент его динамического позиционирования, в котором выри- 
совывается выносливая тенденция определять региональный брендинг как целостность непреходящих ценностей, исключительных и аутентичных характеристик соответствующей территории и сообщества, которые получили всеобщее признание и пользуются популярностью среди различных групп стейкхолдеров.

Ключевые слова: туристическая отрасль, индустрия гостеприимства, брендинг, бренд, туристическая привлекательность, регион.

The article is devoted to the relevance of the development of the tourism industry and the hospitality industry in the modern world. The problems and prospects for the development of tourist attractiveness in the regions have been identified. It is determined that the intensive development of branding in the modern world is due to increased mobility of people, development of tourism and hospitality industry, strengthening communication, the need to create and maintain a positive image of regions that could interest people, encourage them to visit popular places and make long-term investments. The purpose of the article is to analyze the impact of creating a brand of the region on the development of its tourist attractiveness. The article highlights the influence of branding on the formation of a positive image of the territory, increasing the level of its competitiveness and economic development. The views of prominent domestic and foreign scientists regarding the definition of the concept of «brand» are analyzed, their correlation is fulfilled and the concept of «regional tourism brand» is formed, as a set of elements that identify a tourist product or service that a particular region provides among competitors and determine their difference in tourist market. It is characterized that in modern conditions the branding of a region is the most effective tool for its dynamic positioning, in which a strong tendency emerges to define regional branding as the integrity of enduring values, exclusive and authentic characteristics of the respective territory and community, which have received universal recognition and are popular among various groups of stakeholders. Listed activities and their tools that should be used when creating a brand to influence its development of tourist attractiveness of the region. It is determined that the strategy of creating a brand of the region should be consistent with its purpose and goals, take into account regional characteristics and needs of the population, as well as be under the constant control of government agencies. In conclusion, the brand not only promotes the dissemination of information about the country or its region, but also forms public opinion about it and, consequently, contributes to its promotion and economic development.

Keywords: tourism industry, hospitality industry, branding, brand, tourist attraction, region.

Постановка проблеми. Сучасна туристична галузь та індустрія гостинності - це продукти економічної глобалізації, що пов'язані 3 багатьма чинниками, зокрема, з інструментами маркетингу, брендингу, а також концептуальними підходами до просування регіону на туристичному ринку. Туристичний брендинг являє собою процес, який дозволяє розкрити нові можливості та канали комунікації для просування позитивного образу регіону і країни. Особливі туристичні ресурси, національні традиції та пам'ятки, цікава історія, показники, що створюють цілісний образ, на основі якого ідентифрікують певний регіон або країну серед усієї світової спільноти.

Нажаль, образ України та її регіонів у світі сорормовано несистемно, а це приводить низької туристичної привабливості, тим самим зниження економічного рівня. Це й наголошує про необхідність фрормування бренду на основі просування локальних унікальних відмінностей територій і створення позитивного іміджу для підвищення туристичної привабливості регіону на туристичному ринку. Адже бренд не тільки сприяє поширенню інорормації про країну або ії̈ регіон, а й фрормує громадську думку про неї та, як наслідок, сприяє ії популяризації та економічному розвитку.

Аналіз останніх досліджень і публікацій. Тематику створення туристичних брендів у своїх наукових працях досліджувало значна кількість наукових діячів, зокрема, Т. Амблер, С. Анхольт, Б. Барнс, Б. Берман, Дж. Веркман, П. Дойль, С. Девіс, Е. Йохімштайлер, В. Зотов, Д. Келлер, Ф. Котлер, І. Олейнік, А. Панкрухін, Л. Райс, М. Томсон, Р. Чармессон та ін. Щодо розвитку регіональних брендів, то цьому напряму присвячені дослідження В. Білявського, О. Біловодської, Г. Пашкової, М. Селюкова, О.І. Соскіної, Г. Студінської тощо.

Виділення невирішених раніше частин загальної проблеми. Завдяки можливостям сучасного світу, інтерес до туристичних мандрівок стрімко зростає. Однак різноманітні несприятливі фрактори (війни, пандемії, загрози терористичних актів, природні катаклізми тощо) мають не аби який вплив на вибір туристами місця подорожі. Загальний імідж країни і рівень розвитку ії̈ туристичної індустрії $€$ найважливішими стимулювальними чинниками, які впливають на остаточний вибір місця подорожі. Так як брендинг має свою специфріку, відповідно до мети та об'єктів, саме за для підвищення туристичної привабливості нашої країни та її регіонів, слід вважати за потрібним приділити увагу потрібно вивченню особливостей створення бренда окремих міст і територій.

Формулювання цілей статті (постановка завдання). Метою статті $\epsilon$ аналіз впливу ство- 
рення бренду регіону на розвиток його туристичної привабливості.

Виклад основного матеріалу дослідження. Інтенсивний розвиток брендингу В сучасному світі обумовлений підвищенням мобільності людей, розвитком туристичної галузі й індустрії гостинності, посиленням комунікаційного обміну, необхідністю створення та підтримки позитивного іміджу регіонів, який міг би зацікавити людей, спонукати їх до відвідування популярних місць і вкладання довгострокових інвестицій [3].

Перш ніж перейти до аналізу створення туристичного бренду, надамо визначення даного поняття. Існує дуже багато поглядів наукових діячів щодо значення поняття «бренд» [4], деякі з них подано в табл. 1.
Отже, провівши аналіз наукових підходів, було визначено, що бренд - це комплекс маркетингових елементів, застосування, планування, просування та використання яких формують позитивне сприйняття торгової марки чи послуги, створюють проекцію якості продукції та її відмінностей від конкурентів у масовій свідомості з метою впливу на мотивацію туристів щодо придбання послуг та підвищення прибутків за рахунок фрормування додаткової вартості.

Все вище визначене дало змогу сорормувати поняття «регіональний туристичний бренд», який визначається як сукупність елементів, які ідентифікують туристичний продукт або послугу, що надає окремий регіон, серед конкурентів і визначають їх відмінність на туристичному ринку.

Наукові підходи до визначення поняття «бренд"

Таблиця 1

\begin{tabular}{|c|c|c|c|}
\hline Автор & Визначення & Переваги & Не виділено \\
\hline Голубков Є.П. & $\begin{array}{c}\text { «послідовний набір } \\
\text { фрункціональних, емоційних } \\
\text { обіцянок цільовому споживачу, } \\
\text { які є унікальними, важко } \\
\text { імітованими і відповідають } \\
\text { його потребам» }\end{array}$ & $\begin{array}{c}\text { Враховує } \\
\text { психологічні аспекти } \\
\text { впливу бренду } \\
\text { на споживача }\end{array}$ & $\begin{array}{c}\text { Не визначає } \\
\text { стратегічних цілей } \\
\text { побудови бренду } \\
\text { як кінцевої мети } \\
\text { брендінгу }\end{array}$ \\
\hline Гречніков І.М. & $\begin{array}{c}\text { «комплекс думок, почуттів, } \\
\text { асоціацій, які виникають у } \\
\text { людини, коли вона чує чи } \\
\text { бачить певну назву» }\end{array}$ & $\begin{array}{c}\text { Визначає } \\
\text { комплексність } \\
\text { відчуттів споживачів } \\
\text { до бренду }\end{array}$ & $\begin{array}{c}\text { Визначає у якості } \\
\text { елемента бренду } \\
\text { лише назву }\end{array}$ \\
\hline Ільїн А.І. & $\begin{array}{c}\text { «імідж компанії, доповнена } \\
\text { багатьма допоміжними } \\
\text { елементами торгова марка } \\
\text { компанії, проекція торгової } \\
\text { марки на масову свідомість» }\end{array}$ & $\begin{array}{c}\text { Охоплює не лише } \\
\text { окрему групу } \\
\text { споживачів, } \\
\text { а визначає роль } \\
\text { бренду у масовій } \\
\text { свідомості }\end{array}$ & $\begin{array}{c}\text { Не визначає } \\
\text { стратегічних цілей } \\
\text { бренду як кінцевої } \\
\text { мети брендінгу }\end{array}$ \\
\hline Лисиця Н.М. & $\begin{array}{c}\text { Сукупність обіцянок, які } \\
\text { компанія надає своїм клієнтам }\end{array}$ & $\begin{array}{c}\text { Клієнторієнтовне } \\
\text { визначення }\end{array}$ & $\begin{array}{c}\text { Визначення не } \\
\text { має стратегічного } \\
\text { орієнтиру }\end{array}$ \\
\hline Панкрухін А.П. & $\begin{array}{c}\text { Сукупність обіцянок, які } \\
\text { пов'язані із продуктом чи } \\
\text { послугою, що виділяють їх } \\
\text { унікальність по відношенню } \\
\text { до конкурентів, які логічно } \\
\text { виведені шляхом аналізу } \\
\text { позитивних сторін продукту }\end{array}$ & $\begin{array}{c}\text { Визначає } \\
\text { необхідність } \\
\text { робити акцент } \\
\text { на унікальності } \\
\text { продукту }\end{array}$ & $\begin{array}{c}\text { Визначення } \\
\text { не має стратегічного } \\
\text { орієнтиру }\end{array}$ \\
\hline Дінні К. & $\begin{array}{c}\text { Комбінація назви, дизайну, } \\
\text { символів, які ідентифрікують } \\
\text { торгову марку як окремий } \\
\text { бренд у сприйнятті споживачів }\end{array}$ & $\begin{array}{c}\text { Клієнтоорієнтовне } \\
\text { визначення }\end{array}$ & $\begin{array}{c}\text { Не визначає } \\
\text { технологій брендінгу, } \\
\text { що використовується } \\
\text { для його створення }\end{array}$ \\
\hline $\begin{array}{l}\text { Котлер Ф., } \\
\text { Рейн І., } \\
\text { Хайдер Д. }\end{array}$ & $\begin{array}{l}\text { Сукупність матеріальних та } \\
\text { нематеріальних активів, що } \\
\text { ідентиорікують торгову марку }\end{array}$ & $\begin{array}{c}\text { Визначає бренд } 3 \\
\text { точки зору фрінансово- } \\
\text { економічних } \\
\text { складових }\end{array}$ & $\begin{array}{c}\text { Визначення } \\
\text { не має стратегічного } \\
\text { орієнтиру }\end{array}$ \\
\hline
\end{tabular}


У сучасних умовах брендинг регіону - це найбільш результативний інструмент його динамічного позиціонування, в якому вимальовується витривала тенденція визначати регіональний брендинг як цілісність неминущих цінностей, виняткових і автентичних характеристик відповідної території та спільноти, котрі отримали все загальне визнання й користуються популярністю серед населення. Бренд території створюється на базі чітко вираженого позитивного іміджу відповідного регіону, котрий грунтується на виняткових можливостях задоволення тих чи інших потреб населення [2].

Зазвичай конкурентоспроможність будьякого регіону, тим самим його імідж, залежить від наявного ресурсного забезпечення, ступеню розвитку інфрраструктури, техніко-економічного рівня виробництва товарів і послуг, якістю та багатьох інших складових. Саме на це слід звертати увагу в процесі створення бренду регіону за для розвитку його туристичної привабливості.

Бренд регіону не формується природним шляхом, тому що він $€$ продуктом керованого і свідомого осмислення, організованої суспільної ресрлексії та проєктування, що передбачає адміністрування процесами створення й просування бренду регіону, наявність замовника, кваліфрікаційної групи розробників, інфрормаційних і фрінансових ресурсів, чітко ссрормульованого технічного завдання, програми створення та просування, моніторинг ефективності, визначення механізму підтримки та розвитку, - все це вкладається в поняття брендмейкінгу або ж бренд-менеджмент території [1].

Задля аналізу есрективності впливу бренду на розвиток туристичної привабливості регіону, а також впливу на становлення регіональної економіки, при створенні регіонального брендмейкінгу необхідно використовувати певні інструменти відповідно таких видів діяльності:

1. Розвідування найсуттєвіших відмінностей у регіональному розвитку та «родзинок», які визначають індивідуальність та унікальність регіону.

2. З'ясування в межах території регіону фракторів і складових, котрі ймовірно стануть конкурентними перевагами.

3. З'ясування структурних елементів і чинників розвитку, котрі ймовірно стануть базою для створення бренду.

4. Розвідування цільових груп, для котрих являються цінними визначені бренд-срактори.
Бренд регіону взаємопов'язаний з чотирма цільовими аудиторіями: населення, що тимчасово перебуває на території регіону і забезпечує постійні свіжі фрінансові потоки; населення, яке постійно живить економіку регіону; підприємства, установи, організації, що інвестують у регіон, платять податки тощо; вплив розширення зовнішніх ринків.

5. 3'ясування споживацької місткості окремих цільових груп і уточнення орієнтирів регіонального брендмейкінгу.

6. Створення й імплементація комплексу заходів стосовно посилення конкурентних переваг. тегіï.

7. Створення моделі бренду та його стра-

8. Формування програми розвитку бренду і механізму його просування 3 метою зростання економічних ініціатив у регіоні [5].

Отже, основним у просуванні та фрормуванні привабливого іміджу території є стратегія управління цим процесом. Ефективне управління регіональним розвитком у сучасних умовах передбачає необхідність використання інноваційних підходів в управлінні, 3 залученням технологій та інструментів менеджменту, що традиційно $€$ характерними для бізнес-середовища, і які визначають високу ефективність у комерційній сорері. Одним із таких підходів має стати використання регіонального брендингу, який є важливою умовою забезпечення успішного управління регіональним розвитком, підвищення його конкурентоспроможності, економічного і соціального зростання.

Висновки. Таким чином, проведене нами дослідження дає змогу стверджувати, що для ефрективного управління регіональним розвитком необхідно використовувати інноваційні підходи, які сприятимуть зростанню його іміджу та економіки. Одним із таких підходів $€$ створення регіонального бренду, як ефективного засобу підвищення конкурентоспроможності території, тим самим збільшення рівня її туристичної привабливості. Стратегія створення бренду регіону повинна узгоджуватися 3 його метою і цілями, а також ураховувати регіональні особливості й потреби внутрішніх та зовнішніх стейкхолдерів, а якісне управління повинно сорормувати провідні пропозиції щодо просування бренду та періодично проводити моніторинг задля визначення його есрективності.

Перспективи подальшим досліджень полягають в аналізі візуальних і невізуальних засобів створення регіонального бренду. 


\section{СПИСОК ВИКОРИСТАНИХ ДЖЕРЕЛ:}

1. Велещук С. Територіальний брендинг як інструмент соціально-економічного розвитку регіону. Сталий розвиток економіки. 2015. № 3. С. 146-152.

2. Пашкова Г. Брендинг регіону в контексті нової парадигми регіонального розвитку. Державне управління та місцеве самоврядування. Збірник наукових пращь. 2012. Вип. 2(13). URL: http://w.dbuapa.dp.ua/vidavnictvo/ 2012/2012_02(13)/12pggprr

3. Соскіна О. Брендинг міст: досвід країн Вишеградської групи для України. Київ : Видавництво «Інститут транссрормації суспільства», 2011. 80 с.

4. Угоднікова О., Жигло А. Порівняння специфіки та особливостей визначення поняття маркетингу та брендингу у галузі туризму та готельного господарства. Економічні науки. Scientific Journal «ScienceRise». 2017. № 7(36). С. 15-18.

5. Файсура В. Територіальний брендинг у стратегії регіонального розвитку. Регіональні аспекти розвитку продуктивних сил України. 2009. Вип. 14. С. 9-13.

\section{REFERENCES:}

1. Veleshchuk S. (2015) Terytorialnyi brendynh yak instrument sotsialno-ekonomichnoho rozvytku rehionu [Territorial branding as a tool for socio-economic development of the region]. Stalyi rozvytok ekonomiky, vol. 3, pp. 146-152.

2. Pashkova H. (2012) Brendynh rehionu v konteksti novoi paradyhmy rehional'noho rozvytku [Branding of the region in the context of a new paradigm of regional development]. Derzhavne upravlinnia ta mistseve samovriaduvannia. Zbirnyk naukovykh prats', vol. 2, no. 13. URL: http://w.dbuapa.dp.ua/vidavnictvo/2012/2012_02(13)/12pggprr

3. Soskina O. (2011) Brendynh mist: dosvid krain Vyshehradskoi hrupy dlia Ukrainy [City branding: the experience of the Visegrad Group countries for Ukraine]. Kyiv: Vydavnytstvo «Instytut transformatsii suspilstva».

4. Uhodnikova O., Zhyhlo A. (2017) Porivniannia spetsyfiky ta osoblyvostei vyznachennia poniattia marketynhu ta brendynhu u haluzi turyzmu ta hotelnoho hospodarstva [Comparison of the specifics and features of defining the concept of marketing and branding in the field of tourism and hospitality]. Ekonomichni nauky. Scientific Journal «ScienceRise», vol. 7, no. 36, pp. 15-18.

5. Faifura V. (2009) Terytorialnyi brendynh u stratehii rehionalnoho rozvytku [Territorial branding in regional development strategy]. Rehionalni aspekty rozvytku produktyvnykh syl Ukrainy, vol. 14, pp. 9-13. 